\title{
PENGEMBANGAN PROGRAM PEMBELAJARAN PRAKTIKUM FISIKA DASAR BERORIENTASI HEURISTIK TERBIMBING TERHADAP PENINGKATKAN KECAKAPAN AKADEMIK MAHASISWA
}

\author{
Drs. Juliper Nainggolan, M.Si
}

Hermin Manullang

\begin{abstract}
Abstrak
Penelitian ini bertujuan untuk mengetahui pengaruh pengembangan program pembelajaran praktikum fisika dasar berorientasi heuristik terbimbing terhadap peningkatkan kecakapan akademik mahasiswa T.A 2018/2019. Jenis penelitian ini adalah penelitian pengembangan $\mathrm{R} \& \mathrm{D}$ (research and development) dengan desainpenelitian one-shot case study pada uji coba I dan one group pretest-posttest design pada uji coba II. Teknik analisis data melaluianalisis deskriptif kuantitatif, deskriptif kualitatif dan statistik induktif. Dengan populasi penelitian yaitu seluruh mahasiswa program studi pendidikan fisika semester II T.A 2018/2019 dengan jumlah keseluruhan 19 orang mahasiswa. Instrumen yang digunakan adalah (1) lembar observasi untuk mengetahui aktivitas belajar mahasiswa dan kinerja mahasiswa,(2) tes objektif dalam bentuk pilihan berganda dan esai untuk mengetahui peningkatan kecakapan akademik mahasiswa, dan (3) angket untuk mengetahui respon mahasiswa terhadap pembelajaran praktikum fisika berorientasi heuristik terbimbing. Sebelum instrumen ini digunakan terlebih dahulu dilakukan uji validitas dan uji reliabilitas. Setelah dilakukan pembelajaran praktikum fisika dasar berorientasi heuristik terbimbing diperoleh lah,nilai rata-rata aktivitas mahasiswa 84,71 ,nilai rata-rata kinerja mahasiswa 83,89 ,nilai rata-rata respon mahasiswa 88,48 dan nilai rata-rata postes 75,57 dengan standar deviasi 9.45. Nilai ketiga observasi disebut variabei $\mathrm{X}$ dan nilai postes disebut variabel Y kemudian dilakukan uji t dan uji regresi. Hasil uji prasyarat data postes menyatakan sampel terdistribusi normal dan homogen. Dan dilakukan uji $t$ satu pihak $(\alpha=0,05)$. Dari uji t satu pihak dan uji regresi disimpulkan bahwa ada pengaruh pengembangan program pembelajaran praktikum fisika dasar berorientasi heuristik terbimbing untuk meningkatkan kecakapan akademik mahasiswa T.A 2018/2019. Sedangkan hubungan masing-masing variabel diindikasikan berpengaruhsignifikan melalui uji regresi dengan perolehan hasil $\hat{Y}=-64,65+1,65 \mathrm{X}$.
\end{abstract}

Kata kunci : pengembangan program pembelajaran,pembelajaran heuristik terbimbing, kecakapan akademik mahasiswa.

\begin{abstract}
This study aims to determine the effect of guided heuristic-oriented basic physics practicum learning program development to improve academic skills of college students school year 2018/2019. This study is a development study (research and development) with one-shot case study design on the first trial and one group pretest-posttest design on the second trial. Analysis technique of this study through quantitative descriptive analysis, qualitative descriptive and inductive statistics. Population of this study are all 19 second semester students faculty of Education of Physic school year 2018/2019. The instruments used were (1) observation sheets to find out student learning activities and student performance, (2) multiple choice objective tests and essays to find out the improvement of students academic skill, and (3) questionnaire to find out students responses to guided heuristic-oriented basic physics practicum learning. Validity and reliability tests are done before this instrument used. After the guided heuristicoriented basic physics practicum learning done, known that the average value of student activity is 84.71 , the average value of student performance is 83.89 , the average value of student responses is 88.48 and the average post-test score is 75.57 with a standard deviation of 9.45. All of that three value called variable $\mathrm{X}$ and the value of the post-test is called variable $\mathrm{Y}$,
\end{abstract}


then t-test and regression test are performed. The results of the post-test data prerequisite test stated that the sample was normally distributed and homogeneous. One-side t-test was performed $(\alpha=0.05)$, from the one-side t-test and the regression test results concluded that there was an influence of guided heuristic-oriented basic physics practicum learning program development to improve the students academic skill of school year 2018/2019. While the correlation of each variable is indicated to have a significant effect through a regression test with the acquisition of $\widehat{Y}=-64,65+1,65 X$.

Key words : development of learning programs, guided heuristic learning, student academic skills

\section{PENDAHULUAN}

Fisika merupakan salah satu bagian dari sains yang dibangun dari penalaran deduktif dan penemuan induktif (Pandia, 2005:17). Dalam pembelajaran Fisika perlu memperhatikan unsur sains sebagai ilmu pengetahuan teoritis yang diperoleh melalui cara yang khusus, yaitu melakukan pengamatan, percobaan, penyusunan teori, dan penyimpulan yang saling kait-mengkait antara cara satu dengan cara yang lain. Oleh karena itu, proses pembelajaran Fisika seharusnya tidak hanya menyangkut olah pikir, akan tetapi juga memperhatikan olah tangan melalui kerja praktek.

Kegiatan praktikum merupakan suatu cara penyajian pelajaran dimana mahasiswa melakukan percobaan melalui kerja praktek dengan melaksanakan maupun membuktikan sendiri sesuatu yang dipelajari (Sudirman, 1991:163). Kegiatan praktikum akan memberikan kesempatan pada mahasiswa untuk mengalami dan melakukan sendiri, mengikuti suatu proses, mengamati suatu objek, mencari, menganalisis, dan menarik kesimpulan secara mandiri. Hal ini sesuai dengan kurikulum kerangka kualifikasi nasional Indonesia (KKNI) yang memiliki kompetensi kognitif, spikomotorik, afektif, dan sifat, dimana pembelajaran Fisika hendaknya dilaksanakan secara penemuan dan penyelidikan ilmiah untuk menumbuhkan salah satu aspek penting kecakapan hidup yaitu kecakapan akademik (Depdiknas, 2006:377). Kecakapan akademik ini terkait dengan bidang pekerjaan yang lebih memerlukan pemikiran atau kerja intelektual (Depdiknas, 2009:20).
Pendekatan heuristik terbimbing dapat memfasilitasi proses pembelajaran melalui penemuaan dan penyelidikan ilmiah. Menurut Donovan et.al (2005:428), pada setiap aspek pendekatan heuristik terbimbing meyajikan perbedaan tantangan, dimana pada pelaksanaannya menekankan pada aktivitas berpikir disertai dengan aktivitas kinerja. Aktivitas berpikir (mindon) adalah kemampuan mempertanyakan dan mencari jawaban sesuai dengan tingkat pengetahuan mahasiswa dalam memperoleh pemahaman, sedangkan aktivitas kinerja (hand-on) adalah kegiatan penyelidikan ilmiah untuk mencari dan menemukan pengetahuan melalui olah tangan atau kerja praktek. Pendekatan inisangatbaik digunakan untuk mendesain pembelajaran dan mengembangkan kecakapan akademik, karena memberikan ruang kepada mahasiswa untuk belajar sesuai dengan gaya belajar mereka sendiri (Knowlton et.al, 2007:234).

Salah satu mata kuliah yang menyelenggarakan kerja praktek atau kegiatan praktikum di FKIP Universitas HKBP Nommensen Medan adalah mata kuliahFisika Dasar I dan Fisika dasar II. Fisik dari mata kuliah ini merupakan mata kuliah yang harus diprogram oleh mahasiswa dari Program Studi Pendidikan Fisika. Jumlah Sistem Kredit Semester (SKS) pada mata kuliah ini adalah 3/1 SKS yang artinya kuliah secara teori 3 SKS dan praktikum 1 SKS. Praktikum yang ada pada mata kuliahFisika Dasar terbagi menjadi dua yaitu praktikum Fisika Dasar I dan II yang ditawarkan pada semester berbeda. Mata kuliah ini bertujuan untuk memberikan pemahaman kepada 
mahasiswa tentang landasan Fisika bertolak dari pengetahuan Fisika yang telah diperoleh di SMA. Isi praktikum meliputi kegiatan pengenalan berbagai alat ukur dan melatih cara menggunakannya, mengenalkan dasar-dasar eksperimentasi dan melatih menerapkannya dalam praktikum, serta mengembangkan strategi kognitif yang menunjang mata kuliahFisika Dasar.

Kegiatan praktikum Fisika Dasar meliputi tiga tahapan yaitu pralaboratorium, kegiatan laboratorium, dan postlaboratorium. Tahap pralaboratorium merupakan kegiatan untuk mempersiapkan mahasiswa sebelum melakukan praktikum sesungguhnya yang meliputi pemahaman teori, penguasaan alat dan bahan, kemampuan mengidentifikasi variabel, serta metode pengambilan dan pengumpulan data. Tahap kegiatan laboratorium, mahasiswa melakukan kegiatan pengambilan data. Sedangkan pada tahapan postlaboratorium, mahasiswa melakukan pembuatan laporan dan seminar hasil penelitian. Diharapkan melalui kegiatan praktikum Fisika Dasar ini dapat mengembangkan kecakapan akademik yang meliputi penguasaan pengetahuan dan keterampilan ilmiah.

Dari hasil penelitian pendahuluan ditemukan bahwa kecakapan akademik mahasiswa masih belum sesuai dengan harapan. Hal ini dapat dilihat dari hasil tes penguasaan pengetahuan dan keterampilan ilmiah setelah mahasiswa mengikuti kegiatan praktikumyangmasih kurang, dengan nilai rata-rata masing-masing 61,2dan 60,5. Dari hasil tersebut mengindikasikan bahwa perlu disusun program pembelajaran yang fokus terhadap peningkatan kecakapan akademik. Menurut Herry (2008:10.1),program pembelajaran memiliki peran sangat strategis dalam pencapaian tujuan pendidikan yaitu sebagai sarana mengembangkan potensi untuk memperoleh pengetahuan baru.

Hasil surveilapanganterhadap program pembelajaran yang digunakan, ditemukan bahwa: (1) kerangka program hanya sebatas jadwal kegiatan praktikum, seharusnya kerangka program lebih ditekankan pada informasi umum dan garisgaris besar program pembelajaran (GBPP) sebagai landasan dan acuan perencanaan kegiatan praktikum; (2) perangkat pembelajaran yang telah dibuat hanya buku ajar dan lembar kegiatan praktikum sedangkan SAP belum ada, SAP ini penting untuk dikembangkan sebagai panduan dosen/ko-asisten dalam melaksanakan kegiatan pembelajaran; dan (3) lembar penilaian tidak disertai dengan rubrik penilaian yang jelas, hal ini menyebabkan reliabilitas penilaian yang rendah. Dosen pembimbing praktikum Fisika berharap bahwa perlu dibuatkan program pembelajaran praktikum yang diorientasikan pada proses penemuan dan penyelidikan yang terbimbing.

Pelaksanaan pembelajaran masih terlihat beberapa kekurangan terutama dalam hal proses dan pembimbingan. Mahasiswa cenderung untuk melaksanakan instruksi yang diberikan pada langkahlangkah praktikum yang tertulis pada lembar kegiatan praktikum, hal ini secara tidak langsung akan mengurangi kemandirian mahasiswa menemukan sendiri pengetahuan baru dalam proses pembelajaran. Peran dosen/ko-asisten terlihat belum maksimal, hal ini karena dari kurangnya interaksi dengan mahasiswa untuk melakukan pembimbingan dan pencarian informasi terutama pada saat pengumpulan data dan seminar hasil praktikum. Peran dosen seharusnya sebagai fasilitator untuk membimbing praktikum, pemberi pertanyaan, penjelas ide, dan sebagai sumber rujukan.

Pengamatan terhadap penilaian praktikum Fisika Dasar, diketahui bahwa belum ada penilaian kinerja. Penilaian tahap akhir praktikum seharusnya tidak dilakukan dengan tes tulis saja, karena salah satu aspek yang dikembangkan pada mata kuliah praktikum adalah keterampilan laboratorium. Keterampilan laboratorium berhubungan dengan aktivitas kinerja (hands-on activity) sehingga perlu 
dibuatkan penilaian kinerja untuk mengetahui kemampuan kinerja. Penilaian kinerja mengharuskan peserta didik untuk mendemonstrasikan kinerja. Penilaian kinerja didefinisikan sebagai penilaian terhadap proses perolehan, penerapan pengetahuan dan keterampilan melalui proses pembelajaran yang menunjukkan kemampuan peserta didik dalam proses dan produk (Yudyanto, 2009:59).

Berdasarkan hasil temuan pada studi pendahuluan, maka perlu dikembangkan program pembelajaran yang berorientasi heuristik terbimbing. Diharapkan dengan program praktikum Fisika Dasar berorientasi heuristik terbimbing dapat membimbing mahasiswa untuk menemukan konsep Fisika secara mandiri serta dapat meningkatkan kecakapan akademik. Yang menjadi permasalahan dalam penelitian ini adalah bagaimama program pengembangan pembelajaran praktikum Fisika Dasar berorientasi heuristik terbimbing agar dapat meningkatkan kecapakan akademik mahasiswa. Adapun tujuan penelitian ini adalah mendapatkan program pengembangan pembelajaran praktikum Fisika Dasar berorientasi heuristik terbimbing untuk meningkatkan kecapakan akademik mahasiswa. Penelitian ini sangat penting sekali dan sangat mendesak disebabkan sangat mementukan keberhasilan mahasiswa dalam hal meningkatkan kecakapan akademik mahasiswa.

\section{TINJAUAN PUSTAKA}

Kegiatan ini bertujuan untuk membuat kerangka program yang menjadi landasan pembuatan program kegiatan perkuliahan. Kerangka program terdiri dari deskripsi mata kuliah, Garis Besar Program Pembelajaran (GBPP), dan silabus. Langkah-langkah pengembangan kerangka program meliputi: (1) menyusun deskripsi mata kuliah; (2) menyusun tujuan kurikuler; (3) merumuskan tujuan instruksional; (4) menetapkan pokok bahasan serta sub pokok bahasan; (3) pendekatan pembelajaran secara umum; (4) cara penilaian hasil belajar mahasiswa; (5) buku sumber yang disarankan. Tujuan kurikuler adalah tujuan setiap mata kuliah selama program itu diajarkan yang terdiri dari Standar Kompetensi (SK) dan Kompetensi Dasar (KD), sedangkan tujuan instruksional adalah tujuan satuan-satuan pelajaran atau pokok-pokok bahas yang lebih khusus dari tujuan kurikuler. Apabila kelima kegiatan tersebut telah dikerjakan, maka kegiatan selanjutnya ialah menyusun GBPP. Dari GBPP yang telah disusun kemudian dijabarkan dalam bentuk silabus. GBPP dan silabus inilah yang akan digunakan oleh dosen sebagai patokan/acuan dalam pelaksanaan proses belajar mengajar (Djohar, 2003:4).

Mengembangkan

program pembelajaran di kelas dosen perlu mengolah silabus lebih lanjut ke dalam bentuk satuan acara perkuliahan (SAP). Pada dasarnya SAP adalah terjemahan dari persepsi dosen terhadap mata kuliah yang menjadi wewenangnya berdasarkan pemahamannya terhadap kurikulum. Oleh karena itu, apabila pemahaman dosen terhadap kurikulum yang berlaku belum sepenuhnya secara komprehensif maka akan mengakibatkan perencanaan dan pelaksanaan proses belajar mengajar tidak sesuai dengan harapan dan besar kemungkinannya tujuan dari kurikulum itu tidak tercapai.

SAP tersebut terdiri atas: (1) Tujuan instruksional; (2) materi pelajaran; (3) strategi belajar-mengajar; (4) media pembelajaran; dan (5) penilaian hasil belajar. Atas dasar SAP di atas dosen diharapkan akan mengelola proses belajar mengajar secara efektif dan efisien (Djohar, 2003:5). Tujuan instruksional merupakan rumusan kemampuan yang diharapkan dimiliki peserta didik setelah mempelajari suatu topik atau bahasan tertentu. Dalam mengembangkan tujuan instruksional yang harus ditentukan adalah kemampuan apa yang harus dimiliki mahasiswa untuk dapat dinyatakan berhasil atau lulus dari suatu mata kuliah. Syarat-syarat yang harus dipenuhi dalam menyusun tujuan instruksional adalah: 
(1)Menggambarkanapayang

diharapkandapatdilakukanolehmahasiswa dengan denganmenggunakankata kerjayang menunjukkan tingkah laku yang dapatdiamati;(2) Menggambarkan kondisi atau lingkungan yang menunjang tingkah laku mahasiswa, berupa lingkungan fisika atau psikologis; (3) Menunjukkan mutu tingkah laku yang diharapkan dilakukan mahasiswa dalam bentuk ketepatan atau ketelitian, kecepatan, panjangnya dan frekuensi respons (Herry, 2008:10.34)

Materi ajar dapat diajarkan dengan menggunakan bahan ajar. Bahan ajar disusun atas topik/pokok bahasan dan subtopik/sub pokok bahasan. Tiap topik atau subtopik mengandung ide pokok yang relevan dengan tujuan instruksional. Topik atau subtopik tersebut disusun dalam sekuens yang membentuk suatu sekuens bahan ajar. Ada beberapa cara untuk menentukan atau menyusun sekuens bahan ajar diantaranya: (1) sekuen kronologis; (2) sekuen kausal; (3) sekuen struktural; dan (4) sekuen logis (Djohar, 2008:10.35).

Berbagai metode dapat dikembangkan dan digunakan dalam suatu kegiatan pembelajaran. Tidak ada satu strategi yang selalu sesuai untuk digunakan dalam kegiatan pembelajaran. Artinya tidak semua kegiatan pembelajaran dapat dilakukan dengan hanya satu strategi saja, tetapi dapat dilakukan dengan menggunakan variasi strategi mengajar. Terdapat beberapa faktor yang dapat digunakan sebagai pertimbangan dalam memilih strategi pembelajaran yaitu: (1) tujuan instruksional; (2) karakteristik mata kuliah; (3) kemampuan dosen; dan (4) fasilitas yang tersedia (Herry, 2008:11.12).

Media pembelajaran merupakan segala macam bentuk perangsang dan alat yang disediakan untuk mendorong mahasiswa belajar. Terdapat beberapa faktor yang dapat digunakan sebagai pertimbangan pemilihan media pembelajaran yaitu: (1) tujuan instruksional; (2) situasi belajar; (3) kemudahan; (4) ekonomis; (5) fleksibilitas;
(6) kepraktisan; (7) kemampuan dosen (Herry, 2008:11.24).

Untuk mengetahui tingkat pencapaian tujuan instruksional, perumusan alat evaluasi dilakukan setelah perumusan tujuan instruksional. Dalam kegiatan ini perlu ditentukan: (1) evaluasi yang dilaksanakan; (2) jenis alat evaluasi yang digunakan; (3) alat evaluasinya sendiri yang berdasarkan tujuan instruksional yang telah dirumuskan (Herry, 2008:8.38). Pedoman dan kriteria penilaian disusun berdasarkan indikator yang muncul sesuai dengan tujuan penilaian. Pedoman penilaian dapat menggunakan bentuk check list maupun rating scale dan diwujudkan dalam bentuk skor. Kriteria skor didasarkan pada pedoman penilaian yang ada pada satuan pendidikan masing-masing.

\section{Kegiatan Praktikum Fisika}

Praktikum merupakan bagian integral dari kegiatan belajar mengajar (pembelajaran) Fisika. Kegiatan praktikum merupakan suatu cara penyajian pelajaran dimana peserta didik melakukan percobaan melalui kerja praktek dengan mengalami maupun membuktikan sendiri sesuatu yang dipelajari (Sudirman,1991:163). Hal ini menunjukkan betapa pentingnya peranan kegiatan praktikum untuk mencapai tujuan dari pembelajaran Fisika.

Woolnough et.al (dalam Rustaman, 2005) menyatakan tiga manfaat kegiatan praktikum Fisika. Pertama, praktikum membangkitkan motivasi belajar Fisika. Peserta didik yang termotivasi untuk belajar akan bersungguh-sungguh dalam mempelajari sesuatu. Melalui kegiatan praktikum peserta didik diberikan kesempatan untuk memenuhi dorongan rasa ingin tahu dan ingin bisa. Prinsip ini akan menunjang kegiatan praktikum dimana mahasiswa menemukan pengetahuan melalui eksplorasinya terhadap alam. Kedua, praktikum mengembangkan keterampilan dasar melakukan eksperimen. Melakukan eksperimen merupakan kegiatan yang banyak dilakukan oleh para ilmuan. Untuk melakukan eksperimen ini diperlukan beberapa keterampilan dasar 
seperti mengamati, mengestimasi, mengukur, dan memanipulasi peralatan Fisika. Dengan kegiatan praktikum, mahasiswa dilatih untuk mengembangkan kemampuan bereskperimen dengan melatih kemampuan mereka dalam mengobservasi dengan cermat, mengukur secara akurat dengan alat ukur yang sederhana atau lebih canggih, menggunakan dan menangani alat secara aman, merancang, melakukan dan menginterpretasikan eksperimen. Ketiga, praktikum menjadi wahana belajar pendekatan ilmiah.

\section{Pendekatan Heuristik Terbimbing}

Heuristik berasal dari bahasa Yunani yaitu heuriskein yang berarti saya menemukan. Menurut Howe et.al (1993:197), heuristik adalah proses belajar bagaimana untuk belajar. Heuristik memiliki aspek mirip dengan proses metakognisi. Metakognisi diarahkan dan difokuskan pada berpikir tentang berpikir. Metakognisi kemudian memfokuskan pada keterampilan mental dan proses yang digunakan dalam situasi masalah tertentu. Menurut Robert Sternberg (dalam Howe et.al, 1993:198) menggambarkan keterampilan metakomponensial dan pemrosesan informasi sebagai keterampilan metakognitif yang digunakan dalam mencari dan menggambarkan masalah, perencanaan apa yang harus dilakukan dalam mencari solusi suatu masalah, melaksanakan rencana, monitoring dan menilai tindakan.

Pendekatan heuristik merupakan suatu bentuk perancangan pembelajaran dari berbagai aspek pembentukan sistem instruksional yang mengarah pada pengaktifan peserta didik mencari dan menemukan fakta, prinsip dan konsep yang mereka butuhkan (Sagala, 2006:81). Pendekatan ini merupakan suatu pendekatan pembelajaran yang menyajikan sejumlah data dan mahasiswa diminta untuk membuat kesimpulan menggunakan data tersebut.

Pada dasarnya heuristik meliputi dua substrategi yaitu penemuan (discovery) dan penyelidikan (inquiry) (Depdiknas, 2008b:36). Penemuan, yaitu mahasiswa diharuskan menemukan prinsip atau hubungan yang sebelumnya tidak diketahuinya yang merupakan akibat dari pengalaman belajarnya yang telah "diatur" secara cermat dan seksama oleh Dosen. Penyelidikan, yaitu mahasiswabebas memilih atau menyusun objek yang dipelajarinya mulai dari menentukan masalah, mengumpulkan data, analisis data hingga pada kesimpulannya yaitu mahasiswa menemukan sendiri (Sagala, 2006:82).

Menurut Piaget (dalam Slavin, 2004:45) prinsip-prinsip pembelajaran harus menekankan pada (1) pembelajaran melalui penemuan, pengalaman nyata dan pemanipulasian alat, bahan dan media belajar yang lain; (2) peran pendidik sebagai seseorang yang menyiapkan lingkungan yang memungkinkan peserta didik memperoleh berbagai pengalaman belajar yang luas. Pembelajaran dengan menerapkan pendekatan heuristik dapat berperan dalam pembentukan sistem instruksional yang mengarah pada pengaktifan peserta didik mencari dan menemukan sendiri fakta, prinsip, dan konsep yang mereka butuhkan.

Menurut Knowlton et.al (2007:234) pendekatan heuristik sangatbaik digunakan untuk mendesain pembelajaran dan mengembangan keterampilan proses, karena memberikan ruang kepada mahasiswa belajar sesuai dengan gaya belajar mereka. Pendekatan heuristik merupakan pendekatan yang menekankan pada pengembangan aspek kognitif, afektif dan psikomotor secara seimbang sehingga akan dapat menghasilkan kebermaknaan (Depdiknas, 2008:40-41). Pada setiap aspek pendekatan heuristik meyajikan perbedaan tantangan, dimana pada pelaksanaannya menekankan pada kemampuan berpikir dalam menjelasankan ide (berisi konsep dan teori) disertai dengan aktivitas melalui penyelidikan ilmiah (Donovan et.al, 2005:428).

Disamping kelebihan seperti yang telah dijelaskan, pendekatan heuristik juga 
memiliki kelemahan antara lain: (1) tidak semua peserta didik cocok dengan pendekatan ini; (2) pendidik kurang biasa menggunakan pendekatan ini karena faktor kemampuan; (3) pendekatan ini kurang cocok bagi peserta didik yang lamban; dan (4) pendekatan ini menuntut perlengkapan yang memadai.

Pendekatan heuristik memiliki beberapa prosedur yang meliputi: (1) Stimulation yaitu pengajuan permasalahan; (2) Problem statement yaitu mengidentifikasi permasalahan dengan cara membuat rumusan masalah dalam bentuk pertanyaan maupun hipotesis; (3) Data collection yaitu mengumpulkan berbagai informasi yang relevan untuk membuktikan hipotesis; (4) Data processing yaitu pengolahan informasi (5) Verification yaitu menafsirkan informasi yang telah diperoleh; dan (6) Generalization yaitu menarik generalisasi atau kesimpulan tertentu(Rusyan, 1994:177).

Hal-hal yang perlu diperhatikan demi efektifnya program pembelajaran dengan menggunakan pendekatan heuristik antara lain sebagai berikut: (a) Dosen harus membuat perencanaan tentang apa yang harus digali, dicari, diamati, dan ditemukan oleh mahasiswa; (b) Dosen harus memberi motivasi dan semangat yang memadai kepada mahasiswa agar penemuan berjalan dengan baik; (c) Dosen harus memberikan kejelasan yang optimal tentang sasaran, langkah, dan cara-cara penemuan dan penyelidikan kepada seluruh mahasiswa; (d) Dosen harus dapat bertindak sebagai pembimbing dan fasilitator yang memadai dan dapat bertindak objektif (Fachrudin, 1989).

\section{Kecakapan Akademik}

Jenis kecakapan hidup yang perlu ditingkatkan dalam pembelajaran sains sebagai pengetahuan teoritis yang diperoleh dengan cara melakukan pengamatan dan percobaan adalah kecakapan akademik. Menurut Suprapto (2009:15) kecakapan akademik merupakan kecakapan yang dimiliki seseorang untuk dapat menghadapi problema hidup dan kehidupan secara wajar tanpa merasa tertekan, kemudian secara proaktif mencari serta menemukan solusi hingga akhirnya mampu mengatasinya. Kecakapan akademik juga terkait dengan bidang pekerjaan yang lebih memerlukan pemikiran atau kerja intelektual (Depdiknas, 2009:20).

Kecakapan akademik memiliki beberapa aspek penting. Direktorat kepemudaan (dalam Fahrudin, 2007:4), mengemukakan bahwa kecakapan akademik merupakan kecakapan yang meliputi: (1) kemampuan mengidentifikasi variabel; (2) kemampuan menjelaskan hubungan variabel dengan gejala; (3) kemampuan merumuskan hipotesis; (4) kemampuan merancang penelitan; dan (5) kemampuan melaksanakan penelitian. Anwar (2004:30) berpendapat bahwa kecakapan akademik meliputi (1) melakukan identifikasi variabel dan menjelaskan hubungannya; (2) merumuskan hipotesis terjadap suatu kejadian dan (3) merancang dan melaksanakan penelitian untuk membuktikan suatu gagasan atau keingintahuan. Sementara itu menurut Depdiknas (2009:20), kecakapan akademik meliputi: (1) menguasai pengetahuan; (2) merancang dan melakukan penelitian ilmiah; (3) berkomunikasi ilmiah; (4) mengidentifikasi dan menghubungkan variabel; (5) bersikap ilmiah; (6) berpikir strategis; (7) menguasai teknologi; (8) mengambil keputusan; (9) merumuskan masalah; dan (10) bersikap kritis dan rasional. 


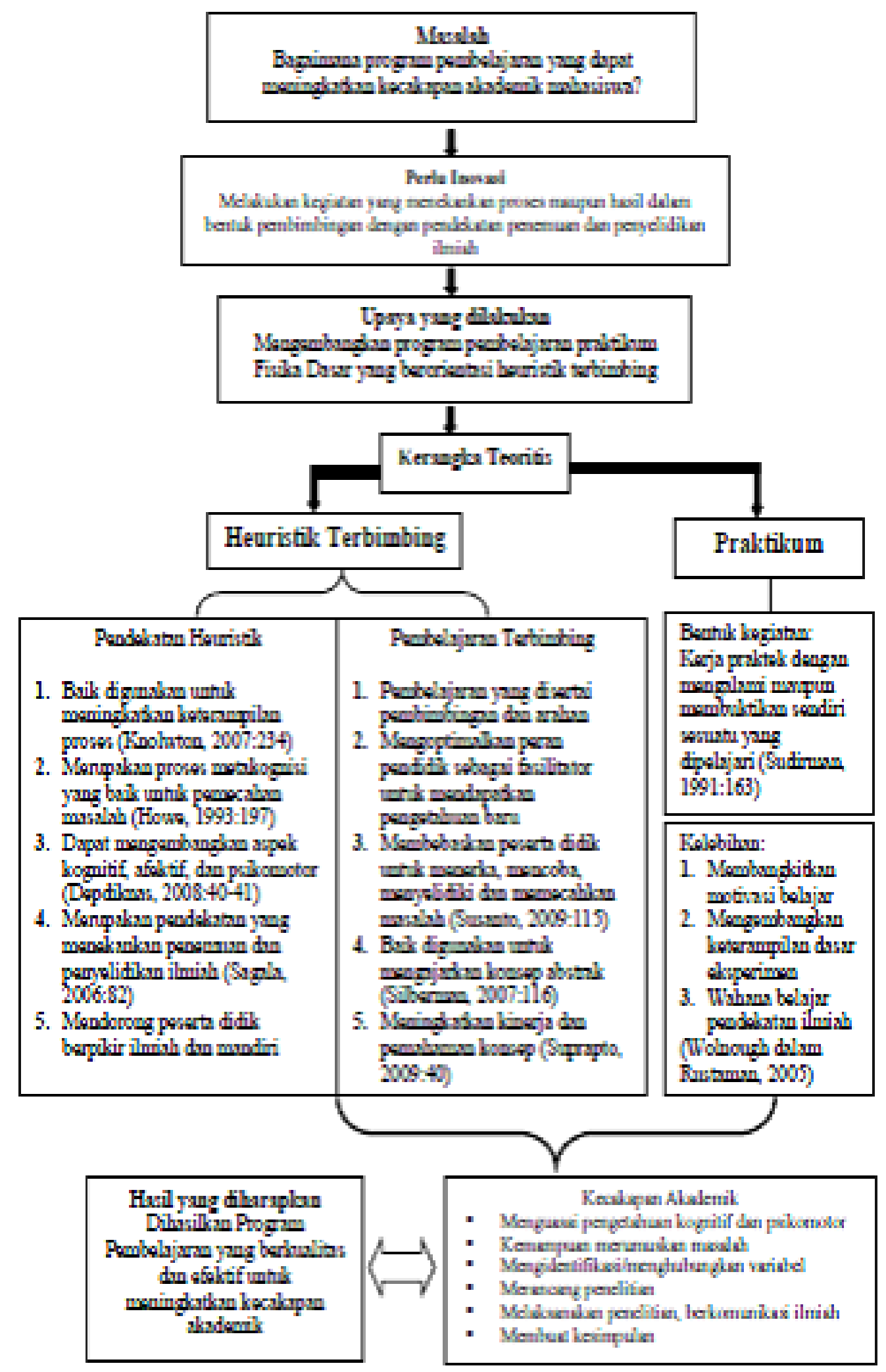

Kerangla Berpilir 


\section{METODOLOGI PENELITIAN}

Penelitian ini dilaksanakan di laboratorium Fisika Dasar Universitas HKBP Nommensen Medan pada bulan Maret sampai bulan Juni 2019. Subjek Penelitian ini adalah mahasiwa program studi pendidikan fisika universitas HKBP Nommensen Medan angkatan 2018. Objek dalam penelitian ini adalah program pengembangan pembejaran praktikum fisika dasar berorientasi heuristik terbimbing dalam meningkatkan kecakapan akademik. Pengumpulan data dilakukan melalui pengisian instrumen angket pembelajaran heuristik terbimbing oleh observator, instrument kecakapan akademik oleh peneliti, dan instrumen respon mahasiswa terhadap pembelajaran heuristic terbimbing oleh mahasiswa. Pengolahan data yang digunakan adalah uji statistik antara lain uji validitas, uji reliabilitas uji normalitas, uji homogenitas, uji hipotesis dan uji regresi linie.

\section{HASIL}

Sebelum instrumen digunakan untuk mengumpulkan terlebih dahulu dilakukan uji validitas dan reliabilitas. Kemudian dilakukan uji normalitas dilakukan dengan menggunakan uji Liliefors untuk mengetahui bahwa data yang diperoleh berdistribusi normal. Melalui Uji Liliefors dengan $\alpha=0.05$ diperoleh harga $\mathrm{L}_{\text {Hitung }}$ dan $\mathrm{L}_{\text {tabel }}$ untuk data pretes maupun postes sampel penelitian.

\begin{tabular}{|c|c|c|c|c|}
\hline No & Data & $\mathbf{L}_{\text {Hitung }}$ & $\mathbf{L}_{\text {tabel }}$ & Kesimpulan \\
\hline 1 & Pretes & 0,118 & 0,195 & Normal \\
\hline 2 & Postes & 0,143 & 0,195 & Normal \\
\hline
\end{tabular}

Dari tabel di atas diketahui bahwa data pretes dan postes berdistribusi normal. Hal ini terlihat dari harga $\mathrm{L}_{\text {Hitung }}<\mathrm{L}_{\text {tabel }}$ yang mengindikasikan bahwa data berdistribusi normal.
Hasil pengamtan tentang aktivitas mahasiswa, kinerja mahasiswa dan respon mahasiswa diperoleh nilai rata-rata 81.14 dan hasil pemberian postes diperoleh nilai rata-rata 75.52. dari hasil uji t satu pihak diperoleh hasil sebagai berikut:

\begin{tabular}{|l|c|c|c|c|}
\hline \multicolumn{1}{|c|}{ Data Kelas } & $\begin{array}{c}\text { Nilai Rata- } \\
\text { rata }\end{array}$ & $\mathbf{t}_{\text {hitung }}$ & $\mathbf{t}_{\text {tabel }}$ & Kesimpulan \\
\hline N.Observasi & 81.14 & \multirow{2}{*}{1.696} & 1,684 & $\begin{array}{c}\text { Ha diterima } \\
\text { (terdapat } \\
\text { pengaruh) }\end{array}$ \\
\hline Postes & 75.52 &
\end{tabular}

Berdasarkan hasil pengolahan data antara variabel $\mathrm{x}$ (aktivitas mahasiswa, kinerja mahasiswa dan respon mahasiswa ) dengan nilai rata rata 81,14 dan vaeiabel y (hasil posttest )penelitian dengan nilai ratarata postes 75.57 maka diperoleh persamaan regresi linear sederhana yaitu $\hat{Y}$ $=-64,65+1,65 \mathrm{X}$.

\section{KESIMPULAN}

Kesimpulan yang diperoleh dari hasil pengembangan adalah sebagai berikut :
1. Telah
dihasilkan perangkat pembelajaran praktikum fisika dasar berorientasi heuristik terbimbing yang layak untuk meningkatkan kecakapan

akademik mahasiswa dengan kualitas modul yang sangat baik.

2. Berdasarkan analisis data secara keseluruhan maka dapat disimpulkan bahwa terdapat pengaruh pengembangan program pembelajaran praktikum fisika dasar berorientasi heuristik terbimbing terhadap peningkatan kecakapan akademik mahasiswa T.A 2018/2019 dengan $\mathrm{t}_{\text {hitung }}=1,70>\quad \mathrm{t}_{\text {tabel }}=1,680 \quad$ dengan persamaan regresi linear sederhana yaitu $\hat{Y}=-64,65+1,65 \mathrm{X}$.

3. Hasil respon mahasiswa terhadap pembelajaran praktikum fisika 


\section{Saran}

dasar berorientasi heuristik terbimbing dikategorikan sangat baik dengan rata-rata nilai sebesar 88,48 yang mendukung pemilihan pendekatan yang tepat dan benar.

Berdasarkan keterbatasan penelitian terdapat beberapa saran untuk perbaikan penelitian pemgembangan pada tahap selanjutnya sebagai berikut :

1. Jumlah observer yang di persiapkan untuk setiap kelompok minimal satu orang sehingga dapat mengamati semua potensi yang ada pada mahasiswa.

2. Dapat dikembangkan untuk materi yang lain

\section{DAFTAR PUSTAKA}

Anwar, 2004. Pendidikan Kecakapan Hidup (Life Skills Education). Bandung:Alfabeta

Depdiknas. 2006. Kurikulum Tingkat Satuan Pendidikan untuk SMP dan MTs. Jakarta: Departemen Pendidikan Nasional

Depdiknas. 2008. Konsep Dasar Kecakapan Hidup. Jakarta: Departemen Pendidikan Nasional

Djohar, 2003. Rancangan Instruksional dan Penyusunan Garis-Garis Besar Program Pengajaran / SAP. Bandung: Koordinator Perguruan Tinggi Swasta Jawa Barat

Depdiknas Donovan, S. and Pellegrino, J. W. 2000. How People Learn: Brain, Mind, Experience, and School. Washington DC: The National Academies Press

Herry, A. 2008. Pengembangan Kurikulum dan Pembelajaran. Jakarta: Universitas Terbuka

Howe, A.C. dan Jones, L. 1993. Engaging Children in Science. New York: Macmillan Publishing Company
Knowlton, D and Thomeczek, M. 2007. Heuristic- Guided Instructional Strategy Development ForPeripheral Learners In The Online Classroom. The Quarterly Review of Distance Education, Volume 8(3), 2007: pp. 233-249

Pandia, W. 2005. Filsafat Ilmu: Diktat Kuliah. Jakarta:STTIP press

Sagala, S. 2003. Konsep dan Makna Pembelajaran. Bandung: Alfabeta

Silberman, M. 1996. Active Learning: 101 Strategies To Teach Any Subject. Massachusettes: Allyn and Bacon

Slavin, R. 2000. Educational Psychology. USA: Allyn and Bacon

Sudirman. 1991. Ilmu Pendidikan. Bandung: Remaja Rosdakarya Gambar 2. Motivasi Belajar Mahasiswa

Sugiono. 2012. Metode Penelitian Pendidikan. Bandung. Alfabeta.

Suprapto, F.A. 2009. Upaya Meningkatkan Kecakapan Akademik (Academic Skills) pada Pembelajaran IPA/Fisika Materi Pemisahan Campuran Menggunakan Problem Base Instruction (PBI). Prosiding Seminar Nasional Fisika Penelitian, Pendidikan, dan Penerapan MIPA UNY 2009: 15- 21

Susanto, A. 2009. Penemuan Terbimbing dalam Pemahaman Konsep. Prosiding Seminar Nasional Fisika Penelitian, Pendidikan, dan Penerapan MIPA UNY 2009: 111117

Yudyanto. 2009. Pengembangan Asesmen Kinerja Melaksanakan Praktikum Elektromagnetik di Jurusan Fisika FMIPA UM 